\title{
EFEKTIVITAS PEMBELAJARAN MELALUI PEMBELAJARAN \\ KOOPERATIF TIPE TGT BERBANTUAN ALAT PERAGA DI KELAS VI SD METHODIST-12 MEDAN PADA KOMPETENSI DASAR LUAS BANGUN DATAR SEDERHANA
}

\author{
OLEH: \\ PATRI JANSON SILABAN \\ (PGSD UNIVERSITAS KATOLIK SANTO THOMAS)
}

\begin{abstract}
The problem in this study are: (1) teachers use teacher-centered approach to the dominance of expository / lecture, (2) the growing culture through books memorizing formulas without any prior explanation, (3) learning-centered book, (4) lack of methods / media / learning strategies, (5) the dominant cognitive learning (knowledge), (6) students are not motivated in the learning of mathematics, and (7) lack of understanding of students' mathematical abilities of the subject matter of mathematics. The purpose of this study is determine the effectiveness of the student. Formulation of the problem in this study, namely: how the effectiveness of the student?

Type of research is action research through cooperative learning TGT aided props as the main target. Where this study seeks to describe the use of cooperative learning TGT props aided in increasing the motivation and ability of students' mathematical understanding through cooperative learning TGT props aided in mathematics in Class VI Elementary School Methodist-12 of Medan. The subjects were students of class VI was 50 of which were 26 men and 24 women in Elementary School Methodist-12 of Medan. Determination of this class is taken based on the observation of the class that will be examined and advice from the principal. Formal object through cooperative learning TGT aided props.

Learning effectiveness of students has increased from an average grade $62.48 \%$ at the cycle I to $76.04 \%$ in the cycle II and become $88.29 \%$ in the cycle III. Thus, it can be concluded that through cooperative learning TGT aided props can increase motivation and understanding of students' mathematical abilities in cognitive, affective and psychomotor widely on the subject of flat wake in Class VI Elementary School Methodist-12 of Medan.
\end{abstract}

Keywords: effectiveness, mathematical understanding, through cooperative learning TGT props aided.

\section{PENDAHULUAN}

\section{Latar Belakang}

Proses belajar merupakan suatu proses yang kompleks yang terjadi pada diri setiap orang sepanjang hidupnya, proses belajar itu terjadi karena adanya interaksi antara seseorang dengan lingkungannya. Oleh karena itu, belajar dapat 
terjadi dimana saja dan kapan saja. Salah satu pertanda bahwa seseorang itu telah belajar adalah dengan adanya perubahan tingkat pengetahuan, keterampilan dan sikapnya. Dalam hal ini, matematika juga perlu dipelajari karena dapat menambah tingkat pengetahuan, keterampilan, sikap terhadap belajar siswa.

Matematika merupakan salah satu materi ajar yang berkaitan dengan mempelajari ide-ide atau konsep yang bersifat abstrak. Hal ini membuat peserta didik beranggapan bahwa matematika merupakan materi ajar yang sulit. Pada kenyataannya banyak peserta didik juga kurang memiliki motivasi dan kemampuan pemahaman matematis terhadap matematika. Hal ini akan berdampak pada kurangnya penguasaan terhadap konsep-konsep dalam matematika. Selain pemahaman konsep dalam matematika, kemampuan pemahaman matematis yang benar juga sangat diperlukan dalam kegiatan pembelajaran matematika. Jika kemampuan pemahaman matematis yang diterima peserta didik salah maka sukar memperbaiki kembali terutama jika sudah diterapkan dalam penyelesaian suatu permasalahan matematis, sehingga penting sekali untuk membuat peserta didik memahami suatu konsep. Aspek-aspek pembelajaran matematika mencakup proses belajar mengajar dan pemikiran yang kreatif. Dalam kegiatan belajar mengajar di sekolah, sering dijumpai berbagai permasalahan. Kesalahan yang dilakukan siswa tidak hanya bersumber pada kemampuan pemahaman matematis siswa yang kurang, tetapi ada faktor lain yang ikut menentukan keberhasilan siswa dalam belajar matematika, salah satu diantaranya adalah metode pembelajaran yang dipilih guru sebagai pengajar.Matematika merupakan suatu syarat untuk melanjutkan pendidikan ke jenjang berikutnya. Karena dengan belajar matematika, siswa akan belajar bernalar secara kritis, kreatif, dan aktif. Matematika merupakan ide-ide abstrak yang berisi simbol-simbol, maka konsepkonsep matematika harus dipahami terlebih dahulu sebelum memanipulasi simbol-simbol itu.

Secara khusus, tujuan pembelajaran Matematika di sekolah dasar, sebagaimana yang disajikan oleh Depdiknas (dalam Susanto 2013:190), sebagai berikut: a) memahami konsep matematika, menjelaskan keterkaitan antar konsep, dan mengaplikasikan konsep atau algoritma, b) menggunakan penalaran pada pola 
dan sifat, melakukan manipulasi matematika dalam generalisasi, menyusun bukti, atau menjelaskan gagasan dan pernyataan matematika, c) memecahkan masalah yang meliputi kemampuan memahami masalah, merancang model matematika, menyelesaikan model, dan menafsirkan solusi yang diperoleh, d) mengomunikasikan gagasan dengan simbol, tabel, diagram, atau media lain untuk menjelaskan keadaan atau masalah, e) mamiliki sikap menghargai penggunaan matematika dalam kehidupan sehari-hari.

Pada kenyataan di lapangan proses pembelajaran matematika yang dilaksanakan pada saat ini belum memenuhi harapan para guru sebagai pengembangan strategi pembelajaran di kelas. Siswa mengalami kesulitan dalam belajar matematika, khususnya dalam menyelesaikan soal yang berhubungan dengan kemampuan pemahaman matematis siswa. Kesulitan yang dialami siswa paling banyak terjadi pada tahap melaksanakan perhitungan dan memeriksa hasil perhitungan. Dengan demikian, kemampuan pemahaman matematis merupakan faktor yang sangat penting bagi perkembangan kognitif siswa dan mempengaruhi motivasi belajar matematika siswa. Hal ini dapat dilihat dalam mengukur kemampuan pemahaman matematis siswa sebagai berikut: Keliling sebuah persegi adalah $48 \mathrm{~cm}$. Berapakah $\mathrm{cm}^{2}$ kah luas bangun persegi tersebut? Dalam penyelesaikan soal tersebut diharapkan siswa menyelesaikan dengan mencari panjang sisi persegi, namun kebanyakan siswa tidak bisa menyelesaikan soal karena siswa menyelesaikan soal tersebut dengan memasukkan angka yang ada dalam soal kedalam rumus luas persegi. Hal ini siswa kurang memahami langkahlangkah penyelesaian masalah karena siswa tidak memiliki kemampuan pemahaman matematis, dimana seharusnya dari tahap perencanaan siswa menyelesaikannya dengan memodelkan dahulu kedalam bentuk matematika sesuai dengan soal, kemudian menyelesaikannya dengan mencari panjang sisi persegi.

Hal ini terlihat dari jawaban siswa tentang soal yang mengukur kemampuan pemahaman matematis siswa mengenai materi luas bangun datar di kelas VI SD Methodist-12 Medan tahun ajaran 2013/2014 sebagai berikut: Sebuah persegi panjang memiliki keliling $100 \mathrm{~cm}$ dengan panjang $20 \mathrm{~cm}$. Hitunglah 
berapa $\mathrm{cm}^{2}$ kah luas persegi panjang tersebut? Pada kenyataannya, siswa tidak menyelesaikan soal tersebut, dimana siswa menjawab pertanyaan tersebut dengan mengalikan langsung angka yang ada pada soal cerita tersebut. Padahal dalam menyelesaikannya harus terlebih dahulu mencari lebar persegi panjang tersebut, setelah itu mengalikan panjang dengan lebar. Maka dengan hal tersebut, luas persegi panjang tersebut dapat diketahui hasilnya. Kasus lain misalnya, Hitunglah luas sebuah lingkaran jika diketahui panjang diameternya $20 \mathrm{~cm}$ !

Berdasarkan soal tersebut banyak siswa langsung memasukkan ke dalam rumus angka yang ada dalam soal tanpa mencari terlebih dahulu panjang jari-jari lingkaran tersebut. Kasus yang lain, Andi membuat empat layangan dengan panjang diagonal pertama $14 \mathrm{~cm}$ dan diagonal kedua $26 \mathrm{~cm}$. Hitunglah berapa luas plastik yang dibutuhkan untuk membuat layangan tersebut! Dalam beberapa kasus di atas ada 15 siswa dari 49 siswa yang kesulitan dalam membuat model matematika dari masalah yang diberikan. Dengan kata lain, siswa belum mampu untuk menerjemahkan data yang ada kedalam satu atau beberapa persamaan yang kemudian penyelesaiannya dari persamaan digunakan untuk menentukan pemecahan masalah matematis. Berdasarkan pengamatan terhadap 50 siswa kelas VI SD Methodist-12 Medan tahun ajaran 2013/2014 dilaksanakan tes tertulis tentang bangun datar, dengan banyak butir tes 10, maka diperoleh hasil tes skor tertinggi 9 dan skor terendah adalah 3, jumlah skor 231 dan rata-rata skor 5,5. Hasil tes ini menunjukkan bahwa kemampuan pemahaman matematis mencari luas bangun datar di kelas VI SD Methodist-12 masih rendah.Sehingga nilai ratarata siswa tidak mencapai nilai ketuntasan yang diharapkan.

Setelah melakukan pengamatan di kelas VI SD Methodist 12 Medan, peneliti mengidentifikasi beberapa hal yang menjadi faktor tidak tuntasnya pembelajaran matematika. Adapun yang menjadi faktor tidak tuntasnya pembelajaran matematika pada pokok bahasan luas bangun datar adalah dalam proses belajar mengajar didalam kelas, guru menggunakan pendekatan yang berpusat pada guru yang dominasi ekspositori/ceramah, tumbuhnya budaya menghafal rumus melalui buku tanpa penjelasan, pembelajaran yang berpusat pada buku, minimnya media/metode/stategi pembelajaran, pembelajaran dominan 
terhadap kognitif (pengetahuan). Sehingga siswa tidak memahami penjelasan dari guru karena merasa jenuh, bosan, dan mengantuk didalam kelas sehingga tidak termotivasi dan tidak memiliki kemampuan pemahaman matematis dalam belajar matematika. Maka pada pertemuan selanjutnya, siswa kurang termotivasi mengikuti pelajaran disebabkan dengan cara yang digunakan dalam penyampaian pesan dalam pembelajaran. Dengan demikian, hasil belajar siswa pada saat ulangan kurang maksimal (belum mencapai nilai ketuntasan). Didalam proses belajar mengajar guru dituntut untuk lebih kreatif dalam menciptakan suasana belajar yang dapat meningkatkan motivasi dan kemampuan pemahaman matematis siswa. Kemampuan pemahaman matematis merupakan suatu proses belajar mengajar tentang suatu bahan pengajaran yang dinyatakan berhasil apabila tujuan pembelajaran dapat tercapai. Tujuan pendidikan adalah untuk mendidik peserta didik menjadi tenaga yang siap pakai.

Menurut Heri (2006:174) mengemukakan bahwa alat peraga disebut juga media pendidikan karena berfungsi membantu dan memeragakan sesuatu dalam proses pendidikan atau pengajaran. Prinsip pembuatan alat peraga, bahwa pengetahuan yang ada pada setiap orang di terima atau di tangkap melalui panca indra. Semakin banyak panca indra yang digunakan maka semakin jelas pula pengertian dan pengetahuan yang diperoleh. Hal ini menunjukkan bahwa keberadaan alat peraga dimaksud kan mengerahkan indra sebanyak mungkin pada suatu objek sehingga memudahkan pemahaman. Menurut penelitian para ahli, panca indra yang paling banyak menyalurkan pengetahuan ke otak adalah mata (kurang lebih $75 \%$ sampai 87\%), sedangkan 13\% sampai 25\% pengetahuan manusia diperoleh atau disalurkan melalui indra lainnya. Oleh karena itu, alat peraga merupakan salah satu alat yang melibatkan alat indra. Hal ini merupakan perpaduan dari metode yang dipergunakan dalam penyampaian informasi kepada siswa.

Berdasarkan fenomena di atas menunjukkan bahwa hasil belajar siswa pada pelajaran matematika belum memuaskan karena masih banyak hasil ujian siswa yang tidak meningkat. Pembelajaran yang cenderung berpusat pada guru membuat respon siswa menjadi kurang baik terhadap pembelajaran matematika 
yang mengakibatkan siswa kurang termotivasi terhadap pelajaran matematika dan membuat siswa kurang aktif dalam proses pembelajaran. Untuk menyikapi permasalahan yang timbul dalam proses pembelajaran matematika, perlu dicari solusi pendekatan pembelajaran yang dapat mengakomodasi meningkatkan motivasi dan kemampuan pemahaman matematis siswa terhadap pelajaran matematika. Menyarankan perubahan dalam pembelajaran matematika ke paradigma baru dengan menciptakan suasana siswa yang aktif, kreatif, efektif, dan menyenangkan yang akan mencegah kebosananan ketika belajar.

\section{Identifikasi Masalah}

Sebagaimana yang telah diuraikan diatas, maka yang menjadi masalah dalam penelitian ini adalah:

1. Guru menggunakanpendekatan yang berpusat pada guru yang dominasi ekspositori/ceramah.

2. Tumbuhnya budaya menghafal rumus melalui buku tanpa penjelasansebelumnya.

3. Pembelajaran yang berpusat pada buku.

4. Minimnya metode/media/stategi pembelajaran.

5. Pembelajaran dominan terhadap kognitif (pengetahuan).

6. Siswa tidak termotivasi dalam pembelajaran matematika.

7. Kurangnya kemampuan pemahaman matematis siswa terhadap materi pelajaran matematika

\section{Batasan Masalah}

Mengingat luasnya cakupan masalah yang teridentifikasi dibandingkan waktu dan kemampuan yang dimiliki, maka peneliti perlu membatasi masalah yang akan dikaji agar analisis hasil penelitian dapat dilakukan dengan lebih mendalam, cermat dan terarah. Oleh karena itu penelitian ini terbatas pada: Efektivitas pembelajaran melalui pembelajaran kooperatif tipe TGT berbantuan alat peraga di kelas VI SD Methodist-12 Medan pada kompetensi dasar luas bangun datar sederhana. 


\section{Rumusan Masalah}

Sesuai dengan batasan masalah diatas, maka peneliti dapat memberikan rumusan masalah pada penelitian ini, yaitu: Bagaimana efektivitas pembelajaran melalui pembelajaran kooperatif tipe TGT berbantuan alat peraga di kelas VI SD Methodist-12 Medan pada kompetensi dasar luas bangun datar sederhana?

\section{Tujuan Penelitian}

Adapun tujuan penelitian ini adalah: Mengetahui keefektifan pembelajaran melalui pembelajaran kooperatif tipe TGT berbantuan alat peraga di kelas VI SD Methodist-12 Medan pada kompetensi dasar luas bangun datar sederhana.

\section{Manfaat Penelitian}

1. Bagi siswa, pembelajaran kooperatif tipe $T G T$ berbantuan alat peraga merupakan salah satu pembelajaran yang memberi kesempatan untuk memperkaya pengalaman belajar anak yang berpusat pada siswa. Dengan demikian, diharapkan siswa tidak lagi menghafal, mendengar, dan sekedar menyelesaikan tugas yang diberikan tetapi berubah menjadi pembelajaran yang aktif, kreatif, kritis, dan menemukan sendiri ilmu yang dipelajari. Penerapan pembelajaran kooperatif tipe TGT berbantuan alat peraga suatu alternatif pembelajaran yang bertujuan untuk meningkatkan motivasi dan kemampuan pemahaman matematis siswa.

2. Bagi guru, penerapan pembelajaran kooperatif tipe $T G T$ berbantuan alat peraga dapat mengembangkan/meningkatkan kemampuan guru dalam mengatasi masalah-masalah pembelajaran pada mata pelajaran Matematika. Penerapan pembelajaran kooperatif tipe TGT berbantuan alat peraga merupakan salah satu alternatif pembelajaran yang bertujuan untuk meningkatkan motivasi dan kemampuan pemahaman matematis siswa.

3. Bagi sekolah atau kelembagaan, penerapan pembelajaran kooperatif tipe $T G T$ berbantuan alat peraga diharapkan dapat mengembangkan/meningkatkan prestasi sekolah melalui peningkatan motivasi dan kemampuan pemahaman matematis siswa. 
4. Bagi peneliti, menjadi suatu kesempatan memperoleh tambahan wawasan mengenai penerapan pembelajaran kooperatif tipe TGT berbantuan alat peraga dalam penyajian Matematika.

\section{METODE PENELITIAN}

\section{Jenis Penelitian}

Jenis pelitian yang dilakukan adalah penelitian tindakan kelas (class room action research). Tujuan penelitian ini untuk memperbaiki kualitas proses dan hasil pembelajaran matematika terkait dengan meningkatkan motivasi belajar siswa, kemampuan pemahaman matematis siswa, dan respon siswa dengan pembelajaran kooperatif tipe TGT berbantuan alat peraga.

\section{Tempat dan Waktu Penelitian}

Penelitian dilaksanakan dikelas VI SD Methodist-12 Medan Tahun Ajaran 2014/2015 yang beralamat di Jalan Panca no.28 Marendal Medan. Adapun alasan pemilihan SD Methodist-12 Medan sebagai tempat penelitian adalah belum ada penelitian tentang meningkatkan motivasi dan kemampuan pemahaman matematis dengan menggunakan pembelajaran kooperatif tipe TGT berbantuan alat peraga yang dilakukan di sekolah tersebut. Pembelajaran selama ini lebih dominan menggunakan matode ekspositori, yang didominasi oleh guru. SD Methodist-12 Medan merupakan unit kerja peneliti sebagai guru yang mengajar di kelas VI. Sebagai unit kerja, peneliti sudah akrab dengan kondisi sekolah dan karakter siswa.

Penelitian ini dilaksanakan pada semester ganjil, berlangsung dari bulan Juni, Juli, dan Agustus 2014 tahun ajaran 2014/2015. Menurut jadwal pelajaran matematika dipelajari 4 x seminggu setiap Senin, Selasa, Rabu, dan Kamis.

\section{Subjek dan Objek Penelitian}

Subjek penelitian ini adalah siswa kelas VI berjumlah 50 yang diantaranya 26 orang laki-laki dan 24 orang perempuan di kelas VI SD Methodist-12 Medan Tahun ajaran 2014/2015. Karakter siswa kelas VI cenderung sama seperti kelaskelas yang lainnya. Karakter siswa pada setiap kelas terdiri dari tingkat kemampuan atau prestasi belajar cepat, sedang, dan lambat. Perempuan dan laki- 
laki usia siswa antara 10 sampai 12 tahun, sosial ekonominya yaitu menengah ke bawah, suku dan agama yang heterogen, dan tingkat pendidikan orang tua siswa yang bervariasi dari SD sampai S2.

Objek yang diamati dalam penelitian ini adalah kemampuan guru mengelola pembelajaran dan aktivitas siswa dalam pembelajaran di kelas dengan menggunakan pembelajaran kooperatif tipe TGT berbantuan alat peraga pada materi luas bangun datar di kelas VI SD Methodist-12 Medan tahun ajaran 2014/2015. Variabel-variabel penelitian yang dijadikan titik fokus untuk menjawab subjek dan objek penelitian adalah (1) motivasi siswa, (2) kemampuan pemahaman matematis siswa, dan (3) pembelajaran kooperatiftipe TGT berbantuan alat peraga.

\section{Rancangan Penelitian}

Penelitian ini menggunakan siklus PTK yang dikemukakan oleh Arikunto (2006:16). Ada beberapa ahli yang mengemukakan rancangan penelitian tindakan dengan berbagai yang berbeda, tetapi secara umum terdapat empat tahapan yang lazim dalam penelitian tindakan, yaitu (1) perencanaan, (2) pelaksanaan, (3) pengamatan, dan (4) refleksi.

Arikunto (2009:75) mengatakan tidak ada ketentuan tentang berapa kali siklus harus dilakukan.Banyak siklus dalam PTK tergantung dari kepuasan peneliti sendiri, namun ada sasaran, sebaiknya tidak kurang dari dua siklus.Sasaran yang dimaksud dapat dirumus oleh peneliti dalam bentuk pencapaian indikator keberhasilan.Dengan mempertimbangkan kondisi siswa, pembelajaran selama ini yang dilakukan, waktu yang tersedia dan tingkat kesulitan materi maka banyak siklus dalam penelitian ini direncanakan tiga siklus.

Lebih rinci tentang rancangan pelaksanaan PTK dalam penelitian ini dijabarkan sebagai berikut:

\section{Siklus I}

Siklus I dalam PTK ini terdiri dari perencanaan, pelaksanaan, pengamatan, dan refleksi sebagai berikut: 


\section{Perencanaan (Planning)}

Pada tahap ini dilakukan diskusi dengan teman sejawat untuk menyusun perencanaan yang akan digunakan dalam tindakan. Perencanaan yang disiapkan seperti: menyusun RPP, mempersiapkan alat peraga yang dibutuhkan, mendesain ruang kelas, membuat lembar observasi untuk guru dan siswa, menyusun LAS, mempersiapkan bahan ajar, mempersiapkan angket respon siswa, dan mempersiapkan perangkat tes serta instrumennya.

Selain peneliti, melakukan validasi perangkat pembelajaran yang digunakan yaitu: rencana pelaksanaan pembalajaran (RPP), lembar aktivitas siswa (LAS), angket motivasi siswa dan instrumen tes kemampuan pemahaman matematis siswa kepada dua orang ahli. Validitas dilakukan dengan meminta pendapat ahli menyangkut isi, bahasa, dan kesesuaian perangkat pembelajaran dengan pembelajaran kooperatif tipe TGT berbantuan alat peraga, kebaikan dan kelemahan perangkat, dan memberikan saran perbaikan. Selanjutnya, pendapat ahli dikuantifikasi yang kemudian di skor dengan cara-cara tertentu.

Sebelum tindakan dilakukan, peneliti juga berdiskusi dengan pengamat untuk membentuk kelompok diskusi siswa yang heterogen dalam pembelajaran. Kelompok heterogen yang dibentuk dengan mempertimbangkan: prestasi belajar siswa, jenis kelamin, suku, sosial ekonomi, kecocokan diantara siswa, dan hal-hal lain yang mempengaruhi agar diskusi kelompok berjalan lancar.

\section{Tindakan (Action)}

Pada tahap ini, peneliti melakukan tindakan di kelas dengan menerapkan pembelajaran kooperatif tipe TGT berbantuan alat peraga berdasarkan perencanaan pembelajaran yang telah dibuat. Dua orang teman sejawat bertindak sebagai pengamat yang bertugas mencatat semua kejadian yang terjadi pada saat tindakan berlangsung. Hal-hal yang menjadi perhatian pengamat adalah aktivitas guru dan aktivitas siswa, dan hal-hal lain yang timbul di dalam kelas pada saat tindakan berlangsung. Adapun langkah-langkah pembelajaran kooperatif tipe TGT berbantuan alat peraga seperti pada tabel berikut. 
Langkah-Langkah Pembelajaran Kooperatif Tipe TGT Berbantuan Alat Peraga

\begin{tabular}{|c|c|c|}
\hline No & Indikator & Kegiatan Guru \\
\hline \multirow[t]{2}{*}{1} & \multirow[t]{2}{*}{ Presentasi kelas } & $\begin{array}{l}\text { Guru menyampaikan tujuan pembelajaran } \\
\text { yang ingin dicapai dan memberi motivasi } \\
\text { siswa supaya dapat belajar dengan aktif } \\
\text { dan kreatif }\end{array}$ \\
\hline & & $\begin{array}{l}\text { Guru menyajikan informasi kepada siswa } \\
\text { dengan menggunakan metode berbantuan } \\
\text { alat peraga sesuai dengan bahan bacaan. }\end{array}$ \\
\hline \multirow[t]{2}{*}{2} & \multirow[t]{2}{*}{ Kelompok } & $\begin{array}{l}\text { Guru menjelaskan kepada siswa } \\
\text { bagaimana caranya membentuk kelompok } \\
\text { belajar dan membantu setiap kelompok } \\
\text { agar melakukan transisi secara efesien. }\end{array}$ \\
\hline & & $\begin{array}{l}\text { Guru membimbing kelompok belajar pada } \\
\text { saat mereka mengerjakan LAS dan tugas- } \\
\text { tugas. }\end{array}$ \\
\hline 3 & Team Game Tournament & 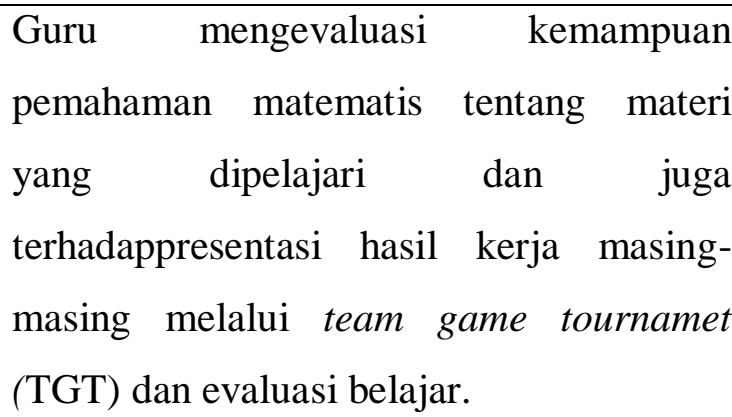 \\
\hline 4 & Memberikan penghargaan & $\begin{array}{l}\text { Guru mencari berbagai cara untuk } \\
\text { menghargai upaya atau keberhasilan hasil } \\
\text { belajar individu maupun kelompok. }\end{array}$ \\
\hline
\end{tabular}

\section{Observasi (Observation)}

Tahapan ini dilakukan pada saat tindakan berlangsung dua orang observer menggunakan lembar observasi aktivitas siswa dan guru yang telah dibuat sebelumnya. Lembar observasi ada dua yaitu lembar observasi untuk aktivitas 
guru dalam mengelola pembelajaran kooperatif tipe TGT berbantuan alat peraga dan lembar aktivitas siswa selama pembelajaran.

Pengamatan terhadap guru meliputi: aktivitas guru dalam mengelola pembelajaran, kegiatan guru pada kegiatan awal pembelajaran, kegiatan inti, dan kegiatan akhir pembelajaran. Sedangkan pengamatan terhatap aktivitas pembelajaran siswa meliputi: keaktifan dalam kelompok, sikap dalam belajar, keaktifan menyelesaikan tugas, dan kemampuan pemahaman materi. Selain menggunakan lembar observasi, pengamat dan peneliti juga menggunakan catatan lapangan.

\section{Refleksi (Reflection)}

Tahapan ini dilakukan setelah tindakan selesai, peneliti dan teman sejawat duduk bersama merefleksikan kegiatan awal pembelajaran dari awal perencanaan sampai evaluasi. Istilah refleksi, dalam bahasa Indonesia berarti pemantulan. Refleksi adalah mengkaji arau memutar ulang secara menyeluruh tindakan yang telah dilakukan. Yang direfleksi mencakup perencanaan pelaksanaan, kelebihan dan kekurangan. Dalam refleksi ini, peneliti dan observer melakukan evaluasi terhadap hal-hal apa yang sudah baik, dan hal-hal apa yang masih kurang atau perlu perbaikan. Terakhir membuat kesimpulan, membuat catatan apa yang harus dilakukan selanjutnya. Data asil refleksi dijadikan acuan untuk melaksanakan tindakan pada siklus selanjutnya.

Tindakan telah berhasil karena telah memenuhi indikator keberhasilan atau ketuntasan kelas sebagai berikut: Efektivitas pembelajaran kooperatif tipe TGT berbantuan alat peraga menunjukkan respon efektif.

\section{Siklus II}

Seperti halnya siklus I, dan siklus II terdiri dari perencanaan, pelaksanaan tindakan, pengamatan, dan refleksi yang dilakukan berdasarkan data-data yang diperoleh pada siklus I. Hasil refleksi pada siklus I dijadikan masukan untuk memperbaiki tindakan pada siklus II. Siklus II berhenti manakala indikator keberhasilan tindakan telah terpenuhi. Jika tidak, maka tindakan dilanjutkan ke siklus III. 


\section{Siklus III}

Seperti halnya siklus I, siklus II, dan siklus III terdiri dari perencanaan, pelaksanaan tindakan, pengamatan, dan refleksi yang dilakukan berdasarkan datadata yang diperoleh pada siklus II. Hasil refleksi pada siklus II menjadi masukan pada siklus III untuk memperbaiki tindakan agar indikator keberhasilan tercapai. Siklus III berhenti dan tidak berlanjut ke siklus berikutnya manakala indikator keberhasilan tidakan telah terpenuhi.

\section{Defenisi Operasional}

\section{Motivasi Belajar}

Motivasi belajar adalah keseluruhan daya gerak di dalam diri siswa yang menimbulkan kegiatan-kegiatan belajar, yang menjamin kelangsungan dari dari kegiatan belajar dan yang memberikan arah pada kegiatan belajar, sehingga tujuan yang dikehendaki siswa dapat tercapai dengan hasil yang memuaskan.

\section{Kemampuan Pemahaman Matematis}

Kemampuan Pemahaman Matematis adalah kesanggupan untuk dapat mengerti atau memahami apa yang telah dipelajari dalam pembelajaran yang mengarah pada upaya pemberian pemahaman. Dalam pemahaman matematis, siswa dilibatkan secara keseluruhan untuk merangsang agar memperhatikan dan menumbuhkan keinginan belajar memahami masalah pembelajaran. Dengan memahami pembelajaran, siswa akan lebih mudah dalam menyelesaikan masalah yang dihadapainya.

\section{Pembelajaran Kooperatif Tipe TGT Berbantuan Alat Peraga}

Metode TGT (Team Game Tournament) adalah suatu pembelajaran yang didahului dengan penyajian materi pembelajaran melalui alat peraga oleh guru dan diakhiri dengan memberikan sejumlah pertanyaan kepada siswayang menempatkan siswa dalam kelompok-kelompok belajar yang beranggotakan 5 sampai 6 orang siswa yang memiliki kemampuan, jenis kelamin dan suku atau ras yang berbeda.

\section{Instrumen dan Teknik Pengumpulan Data}

Baik buruknya hasil penelitian sangat tergantung pada instrumen dan cara pengumpulan data yang dilakukan. Untuk mendapatkan data yang benar dan 
akurat dilakukan dangan menggunakan metode pengumpulan data sebagai berikut:

\section{Observasi atau Pengamatan}

Observasi adalah pengamatan langsung yang dilakukan untuk memperoleh data berupa aktivitas siswa selama pembelajaran dan kemampuan guru mengelola pembelajaran.Pengamatan dilakukan dengan mencatat secara sistematik kejadiankejadian, perilaku dan hal-hal lain yang timbul pada saat pembelajaran berlangsung.

\section{a.Observasi Aktivitas Siswa selama Pembelajaran}

Lembar pengamatan siswa berisi tentang aktivitas siswa selama pembelajaran berlangsung.Dalam penelitian ini hasil pengamatan ditulis dengan memberikan skor menurut skala yang telah ditentukan.Skor yang diberikan antara 0 sampai 4. Skor 0 berarti tidak ada deskriptor yang muncul, skor 1 berarti satu deskriptor yang muncul, skor 2 berarti dua deskriptor yang muncul, skor 3 berarti tiga deskriptor yang muncul, dan skor 4 berarti semua deskriptor yang muncul melakukan aktivitas siswa selama pembelajaran adalah seperti pada tabel berikut:

\section{Indikator Aktivitas Siswa terhadap Pembelajaran}

\begin{tabular}{|c|c|c|c|}
\hline No & $\begin{array}{l}\text { Aspek yang } \\
\text { Diamati }\end{array}$ & Deskriptor & Skor Siswa \\
\hline \multirow[t]{4}{*}{1} & \multirow{4}{*}{$\begin{array}{l}\text { Melakukan } \\
\text { aktivitas } \\
\text { keseharian }\end{array}$} & Menjawab salam & \\
\hline & & Menjawab absensi & \\
\hline & & Mendengarkan informasi guru & \\
\hline & & Merespon guru dalam kelengkapan kelas & \\
\hline \multirow[t]{4}{*}{2} & \multirow{4}{*}{$\begin{array}{l}\text { Keterlibatan } \\
\text { dalam } \\
\text { pembangkitan } \\
\text { pengetahuan awal }\end{array}$} & $\begin{array}{l}\text { Menjawab/menyampaikan pengalaman } \\
\text { tentang materi }\end{array}$ & \\
\hline & & Mengemukakan pendapat & \\
\hline & & Mengingat materi & \\
\hline & & Siswa bertanya & \\
\hline \multirow[t]{4}{*}{3} & \multirow{4}{*}{\begin{tabular}{lr}
\multicolumn{2}{l}{ Pemahaman } \\
tugas/ peran \\
dalam kegiatan \\
belajar
\end{tabular}} & Mendengarkan penjelasan tugas & \\
\hline & & Membagi tugas sesaui dengan kesepakatan & \\
\hline & & Menerima keberadaan kelompok & \\
\hline & & Serasi dengan kelompok & \\
\hline \multirow[t]{4}{*}{4} & \multirow{4}{*}{ Kegiatan umum } & Tertib & \\
\hline & & Bertanya & \\
\hline & & Mengajukan pendapat & \\
\hline & & Memperhatikan penjelasan guru & \\
\hline
\end{tabular}




\begin{tabular}{|c|c|c|}
\hline \multirow[t]{4}{*}{5} & \multirow{4}{*}{$\begin{array}{l}\text { Ketertiban dalam } \\
\text { kemampuan } \\
\text { pemahaman } \\
\text { matematis } \\
\text { berbantaun alat } \\
\text { peraga }\end{array}$} & Memperhatikan penjelasan guru \\
\hline & & Mengungkapkan data/fakta \\
\hline & & Membuat pertanyaan \\
\hline & & Membuat penyelesaian soal \\
\hline \multirow[t]{4}{*}{6} & \multirow{4}{*}{$\begin{array}{l}\text { Menanfaatkan } \\
\text { alat peraga }\end{array}$} & Memegang alat peraga \\
\hline & & Menjelaskan alat peraga \\
\hline & & Mendengarkan pertanyaan \\
\hline & & Menjawab pertanyaan \\
\hline \multirow[t]{4}{*}{7} & \multirow[t]{4}{*}{ Diskusi kelompok } & Tertib \\
\hline & & Bertanya \\
\hline & & Menjawab \\
\hline & & Menuliskan hasil diskusi \\
\hline \multirow[t]{4}{*}{8} & \multirow{4}{*}{$\begin{array}{l}\text { Kemampuan } \\
\text { bertanya }\end{array}$} & Tunjuk tangan \\
\hline & & Kesopanan \\
\hline & & Keterampilan bertanya \\
\hline & & Keretampilan berbicara \\
\hline \multirow[t]{4}{*}{9} & \multirow{4}{*}{$\begin{array}{l}\text { Menjawab } \\
\text { pertanyaan }\end{array}$} & Tunjuk tangan \\
\hline & & Kesopanan \\
\hline & & Keterampilan bertanya \\
\hline & & Keretampilan berbicara \\
\hline \multirow[t]{4}{*}{10} & \multirow{4}{*}{$\begin{array}{l}\text { Mempersiapkan } \\
\text { hasil diskusi } \\
\text { kelompok }\end{array}$} & Kesiapan hasil diskusi \\
\hline & & Kesiapan alat/bahan \\
\hline & & Kesiapan kelompok \\
\hline & & Kesiapan antar kelompok \\
\hline \multirow[t]{4}{*}{11} & \multirow{4}{*}{$\begin{array}{l}\text { Persentase } \\
\text { kelompok }\end{array}$} & Sikap \\
\hline & & Keterampilan menyampaikan \\
\hline & & Keterampilan mendengarkan pertanyaan \\
\hline & & Keterampilan menjawab pertanyaan \\
\hline \multirow[t]{4}{*}{12} & \multirow{4}{*}{$\begin{array}{l}\text { Kemampuan } \\
\text { menyajikan hasil } \\
\text { diskusi }\end{array}$} & Sikap \\
\hline & & Keterampilan menyampaikan \\
\hline & & Keterampilan mendengarkan pertanyaan \\
\hline & & Keterampilan menjawab pertanyaan \\
\hline \multirow[t]{4}{*}{13} & \multirow{4}{*}{$\begin{array}{l}\text { Melakukan } \\
\text { Turnamen }\end{array}$} & Ketertiban \\
\hline & & Kemampuan menjawab soal \\
\hline & & Kebersamaan kelompok \\
\hline & & Kemampuan menyimak/mendengarkan \\
\hline \multirow[t]{4}{*}{14} & \multirow{4}{*}{$\begin{array}{l}\text { Melakukan } \\
\text { evaluasi } \\
\text { pembelajaran }\end{array}$} & Mendengarkan \\
\hline & & Bertanya \\
\hline & & Menjawab pertanyaan \\
\hline & & Menuliskan hasil evaluasi \\
\hline \multirow[t]{3}{*}{15} & \multirow{3}{*}{$\begin{array}{l}\text { Rangkuman } \\
\text { materi }\end{array}$} & Memberikan perhatian \\
\hline & & Mengidentifikasi aktivitas \\
\hline & & Membuat kesimpulan \\
\hline
\end{tabular}




\begin{tabular}{|c|c|c|}
\hline & & Menuliskan kesimpulan \\
\hline \multirow[t]{4}{*}{16} & \multirow{4}{*}{$\begin{array}{l}\text { Menanggapi } \\
\text { evaluasi }\end{array}$} & Bertanya \\
\hline & & Menjawab pertanyaan guru \\
\hline & & Menjawab pertanyaan teman \\
\hline & & Keterampilan bertanya \\
\hline \multirow[t]{4}{*}{17} & \multirow{4}{*}{$\begin{array}{l}\text { Melakukan } \\
\text { aktivitas } \\
\text { keseharian }\end{array}$} & Menjawab salam \\
\hline & & Kembali duduk keposisi semula \\
\hline & & Mendengarkan informasi guru \\
\hline & & Mendengarkan saran guru untuk belajar \\
\hline \multicolumn{3}{|c|}{ Jumlah Skor } \\
\hline
\end{tabular}

\section{b. Observasi Kemampuan Guru Mengelola Pembelajaran}

Lembar pengamatan guru berisi tentang aktivitas guru mengelola pembelajaran.Hasil pengamatan ditulis dengan memberikan skor menurut skala yang telah ditentukan. Indikator-indikator yang diamati pada kemampuan guru dalam pengelolaan pembelajaran pembelajaran kooperatiftipe TGT berbantuan alat peraga seperti pada tabel berikut:

\section{Indikator Kemampuan Guru dalam Pengelolaan Pembelajaran Kooperatif}

Tipe TGT Berbantuan Alat Peraga

\begin{tabular}{|c|c|c|c|c|}
\hline Kegiatan & Aspek yang diamati & Deskriptor & \multicolumn{2}{|c|}{ Skor } \\
\hline 1 & 2 & 3 & 4 & 5 \\
\hline \multirow[t]{19}{*}{ 1. Awal } & \multirow{4}{*}{$\begin{array}{l}\text { 1.Melakukan aktivitas } \\
\text { keseharian }\end{array}$} & a. Mengucapkan salam & & \\
\hline & & b. Mengabsen siswa & & \\
\hline & & c.Menginformasikan materi yang akan dipelajari & & \\
\hline & & d.Memeriksa kelengkapan kelas & & \\
\hline & \multirow[t]{4}{*}{ 2.Menyampaikan tujuan } & a.Tujuan disampaikan diawal pembelajaran & & \\
\hline & & b.Tujuan pembelajaran sesuai dengan materi & & \\
\hline & & c.Tujuan sesuai dengan LAS & & \\
\hline & & d.Menjelaskan pentingnya pelajaran & & \\
\hline & \multirow{4}{*}{$\begin{array}{l}\text { 3. Membangkitkan motivasi } \\
\text { siswa }\end{array}$} & a.Menyapa siswa & & \\
\hline & & b.Memberikan pujian & & \\
\hline & & c.Memberikan contoh & & \\
\hline & & d.Membangkitkan semangat & & \\
\hline & \multirow[t]{4}{*}{$\begin{array}{l}\text { 4.Membangkitkan } \\
\text { pengetahuan awal }\end{array}$} & $\begin{array}{l}\text { a.Menanyakan pengetahuan atau pengalaman } \\
\text { siswa tentang materi }\end{array}$ & & \\
\hline & & $\begin{array}{l}\text { b.Mengaitkan materi dengan pengetahuan yang } \\
\text { telah dipelajari siswa }\end{array}$ & & \\
\hline & & $\begin{array}{l}\text { c.Mengingatkan kembali materi prasyarat yang } \\
\text { dibutuhkan }\end{array}$ & & \\
\hline & & d.Meminta siswa untuk bertanya & & \\
\hline & \multirow[t]{3}{*}{ 5.Mengorganisasikan siswa } & a.Membentuk kelompok siswa & & \\
\hline & & b.Menjelaskan tugas siswa & & \\
\hline & & c.Menjelaskan tugas individu dalam kelompok & & \\
\hline
\end{tabular}




\begin{tabular}{|c|c|c|c|}
\hline & & d.Mengatur formasi tempat duduk siswa & \\
\hline & \multirow{4}{*}{$\begin{array}{l}\text { 6.Menyediakan sarana dan } \\
\text { prasarana }\end{array}$} & a.Memberikan alat peraga dan lembar kerja siswa & \\
\hline & & b.Alat peraga sesuai dengan LAS & \\
\hline & & c.Alat peraga sesuai dengan tujuan & \\
\hline & & d.Alat peraga dan LAS mengarah kerja siswa & \\
\hline Inti & \multirow[t]{4}{*}{ 1. Menysmpaikan informasi } & a.Suara tegas & \\
\hline \multirow{15}{*}{$\begin{array}{l}\text { 1.Persentase } \\
\text { kelas }\end{array}$} & & b.Memperhatikan keadaan kelas & \\
\hline & & c. Sesuai dengan indikator & \\
\hline & & d.Memberikan kesempatan bertanya & \\
\hline & \multirow{4}{*}{$\begin{array}{l}\text { 2. Menyampaikan berbagai } \\
\text { masalah kontekstual }\end{array}$} & a.Fakta yang diberikan sesuai dengan materi & \\
\hline & & $\begin{array}{l}\text { b.Fakta yang diberikan ada pada LAS atau } \\
\text { disampaikan secara lisan }\end{array}$ & \\
\hline & & $\begin{array}{l}\text { c.Fakta yang disajikan brasal dari kehidupan } \\
\text { sehari-hari }\end{array}$ & \\
\hline & & $\begin{array}{lccc}\text { d.Fakta yang diberikan sesuai dengan } \\
\text { perkembangan intelektual siswa }\end{array}$ & \\
\hline & \multirow{4}{*}{$\begin{array}{l}\text { 3.Menyampaikan masalah } \\
\text { secara bersama-sama }\end{array}$} & a.Memberikan contoh masalah & \\
\hline & & b.Menyelesaikan masalah & \\
\hline & & $\begin{array}{l}\text { c.Memberikan kesempatan kepada siswa untuk } \\
\text { bertanya }\end{array}$ & \\
\hline & & d.Menjawab pertanyaan siswa & \\
\hline & \multirow{4}{*}{$\begin{array}{l}\text { 4. Meminta siswa untuk } \\
\text { menjelaskan kembali }\end{array}$} & a.Memilih secara acak & \\
\hline & & b.Membantu siswa menjelaskan kembali & \\
\hline & & c.Meminta siswa untuk bertanya & \\
\hline & & d.Membantu siswa menjawab pertanyaan & \\
\hline \multirow[t]{21}{*}{ 2.Kelompok } & \multirow{4}{*}{$\begin{array}{l}\text { 1. Membentuk siswa yang } \\
\text { heterogen }\end{array}$} & a.Membentuk kelompok & \\
\hline & & b.Membagi jumlah kelompok & \\
\hline & & c.Penempatan siswa sesuai dengan kemampuan & \\
\hline & & $\begin{array}{l}\text { d.Penempatan kelompok sesuai dengan jenis } \\
\text { kelamin }\end{array}$ & \\
\hline & \multirow{4}{*}{$\begin{array}{l}\text { 2. Membagi LAS yang } \\
\text { berisikan masalah }\end{array}$} & a.Menjelaskan cara menyelesaikan soal & \\
\hline & & $\begin{array}{l}\text { b.Menjelaskan langkah-langkah menyelesaikan } \\
\text { soal }\end{array}$ & \\
\hline & & $\begin{array}{l}\text { c.Menanyakan pada siswa apa cara yang dapat } \\
\text { digunakan }\end{array}$ & \\
\hline & & d.Memberi contoh penyelesaian & \\
\hline & \multirow{4}{*}{$\begin{array}{l}\text { 3. Membantu siswa dalam } \\
\text { berbagai tugas }\end{array}$} & a.Membimbing siswa menyelesaikan soal & \\
\hline & & b.Menanyakan hambatan yang dialami siswa & \\
\hline & & c.Memantau kegiatan penyelesaian oleh siswa & \\
\hline & & d.Memberi tanggapan terhadap jawaban siswa & \\
\hline & \multirow[t]{4}{*}{ 4. Membimbing siswa } & a. Perorangan & \\
\hline & & b.Perkelompok & \\
\hline & & c.Keseluruhan & \\
\hline & & d.Kebutuhan khusus & \\
\hline & \multirow{4}{*}{$\begin{array}{lr}5 . \quad \text { Mengamati } & \text { dan } \\
\text { mengawasi } & \text { semua } \\
\text { kelompok } & \end{array}$} & a. Perorangan & \\
\hline & & b.Perkelompok & \\
\hline & & c.Keseluruhan & \\
\hline & & d.Kebutuhan khusus & \\
\hline & 6. Memberi bantuan kepada & a. Perorangan & \\
\hline
\end{tabular}




\begin{tabular}{|c|c|c|c|}
\hline & \multirow{3}{*}{$\begin{array}{ll}\text { kelompok } & \text { yang } \\
\text { membutuhkan } & \end{array}$} & b.Perkelompok & \\
\hline & & c.Keseluruhan & \\
\hline & & d.Kebutuhan khusus & \\
\hline \multirow{20}{*}{$\begin{array}{l}\text { 3.Tournamen } \\
\mathrm{t}\end{array}$} & \multirow{4}{*}{$\begin{array}{l}\text { 1. Membantu siswa dalam } \\
\text { mempersiapkan laporan }\end{array}$} & a. Perorangan & \\
\hline & & b.Perkelompok & \\
\hline & & c.Keseluruhan & \\
\hline & & d.Kebutuhan khusus & \\
\hline & \multirow{4}{*}{$\begin{array}{lr}\text { 2.membantu siswa dalam } \\
\text { mempersentasekan } \\
\text { diskusi }\end{array}$} & a.Mengorganisasikan penyajian penyelesaian soal & \\
\hline & & $\begin{array}{l}\text { b.Membimbing siswa menyajikan penyelesaian } \\
\text { soal }\end{array}$ & \\
\hline & & c.Menanggapi penyajian siswa & \\
\hline & & d.Memberi penguatan & \\
\hline & \multirow{4}{*}{$\begin{array}{l}\text { 3.Meminta kelompok lain } \\
\text { untuk bertanya }\end{array}$} & a. Perorangan & \\
\hline & & b.Perkelompok & \\
\hline & & c.Keseluruhan & \\
\hline & & d.Kebutuhan khusus & \\
\hline & \multirow{4}{*}{$\begin{array}{l}\text { 4.Membantu siswa dalam } \\
\text { turnamen }\end{array}$} & a. Perorangan & \\
\hline & & b.Perkelompok & \\
\hline & & c.Keseluruhan & \\
\hline & & d.Kebutuhan khusus & \\
\hline & \multirow{4}{*}{$\begin{array}{lr}\text { 5.Membaca } & \text { dan } \\
\text { menyampaiakn } & \text { soal } \\
\text { turnamen } & \end{array}$} & a. Tegas & \\
\hline & & b. Tidak bertele-tele & \\
\hline & & c. Tidak memihak kepada satu kelompok & \\
\hline & & d. Semangat & \\
\hline \multirow{4}{*}{$\begin{array}{l}\text { 4.Penghargaa } \\
\mathrm{n} \text { kelompok }\end{array}$} & \multirow{4}{*}{$\begin{array}{ll}1 . & \text { Memberikan } \\
\text { penghargaan } & \end{array}$} & a.Pujian & \\
\hline & & b.Hadiah & \\
\hline & & c.Memberi arahan & \\
\hline & & d.memberi motivasi & \\
\hline \multirow[t]{9}{*}{ Akhir } & \multirow[t]{4}{*}{ 1.Memberikan tugas } & a. Sesuai materi & \\
\hline & & b. Sesuai indikator & \\
\hline & & c. Jelas & \\
\hline & & d. Mengingatkan kembali & \\
\hline & \multirow[t]{4}{*}{ 2.Mengakhiri pembelajaran } & a.Berdoa & \\
\hline & & b.Mengucapkan salam & \\
\hline & & $\begin{array}{l}\text { c.Menginformasikan materi pada pertemuan } \\
\text { berikutnya }\end{array}$ & \\
\hline & & d.Memotivasi siswa belajar & \\
\hline & \multicolumn{2}{|l|}{ Jumlah Skor } & \\
\hline
\end{tabular}

Skor yang diberikan untuk kemampuan guru dalam mengelola pembelajaran antara 0 sampai 4 untuk setiap indikator penilaian. Skor 0 berarti tidak ada deskriptor yang muncul, skor 1 berarti satu deskriptor yang muncul, skor 2 berarti dua deskriptor yang muncul, skor 3 berarti tiga deskriptor yang muncul, dan skor 4 berarti semua deskriptor muncul dalam melakukan aktivitas atau indikator pada setiap kegiatan pembelajaran. 


\section{Teknik Analisa Data dan Indikator keberhasilan}

\section{Analisa Data}

Setelah data terkumpul dari hasil pengumpulan data, maka segera dilakukan analisa data.Teknik analisa data yang hendak dilakukan oleh peneliti adalah secara kualitatif dan kuantitatif berdasarkan data hasil observasi oleh pengamat. Langkah-langkah yang dilakukan dalam analisa data penelitian tindakan kelas ini adalah sebagai berikut:

\section{Aktivitas Belajar}

Aktivitas belajar siswa dan guru diobservasi pada saat pelaksanaan tindakan. Data pengamatan yang diperoleh dianalisis dengan menentukan persentase skor rata-rata aktivitas siswa, dan kemudian ditentukan kriteria keberhasilannya.

Skor aktivitas belajar siswa dihitung dengan menggunakan rumus:

Persentase skor rata-rata $($ SR $)=\frac{\text { Jumlah Skor }}{\text { Skor Maksimal }} \times 100 \%($ Tamrin, 2003:66)

Interpretasi skor rata-rata sebagai berikut:

$90 \% \leq \mathrm{SR} \leq 100 \% \quad$ : Sangat Baik

$80 \% \leq \mathrm{SR}<90 \% \quad$ : Baik

$70 \% \leq \mathrm{SR}<80 \% \quad$ : Cukup

$60 \% \leq \mathrm{SR}<70 \% \quad$ : Kurang

$00 \% \leq \mathrm{SR}<60 \% \quad$ : Sangat Kurang

Kriteria keberhasilan tindakan untuk aspek aktivitas siswa tercapai bila SR $\geq 80 \%$ (Tamrin,2003:174) dan Kriteria ketuntasan belajar secara klasikal tercapai bila $\mathrm{P} \geq 85 \%$ (Kriteria ketuntasan di SD Methodist-12 Medan).

\section{Indikator Keberhasilan}

Indikator kinerja yang digunakan dalam ukuran "keberhasilan" atau "ketuntasan" terhadap tindakan yang dilakukan dalam satu siklus penelitian menggunakan dua indikator yaitu keberhasilan proses pembelajaran adalah suksesnya siswa dalam mengikuti kegiatan pembelajaran dan suksesnya proses belajar mengajar adalah hasil belajar siswa. Terdapat dua kategori ketuntasan yaitu perorangan dan klasikal. Berdasarkan penjelasan di atas, tindakan telah berhasil dalam penelitian ini karena sudah memenuhi kriteria sebagai berikut: 
Aktivitas siswa salama pembelajaran telah berhasil atau efektif, karena sudah mencapai ketegori baik yaitu $\mathrm{SR} \geq 80 \%$ untuk setiap aspek dan rata-rata persentase keseluruhan dan $85 \%$ siswa mencapai nilai $>\mathrm{KKM}$

\section{HASIL PENELITIAN DAN PEMBAHASAN}

\section{Pembahasan Hasil Penelitian}

Berdasarkan analisis data hasil penelitian diperoleh selama tindakan berlangsung dan temuan-temuan dilapangan setelah diterapkan pembelajaran kooperatif tipe TGT berbantuan alat peraga. Hasil pengamatan selama tindakan berlangsung, ditemukan bahwa proses pembelajaran adalah efektif. Hal tersebut ditunjukkan dengan hasil pengamatan aktivitas siswa dan guru telah memenuhi indikator keberhasilan yang ditetapkan.Keberhasilan indikator tersebut dibahas sebagai berikut.

\section{a. Aktivitas Siswa selama pembelajaran}

Peningaktan aktivitas siswa dengan kegiatan pembelajaran kooperatif tipe TGT berbantuan alat peraga. Temuan ini memberikan jawaban terhadap tindakan yang dikemukakan sebelumnya. Dengan demikian, dapat disimpulkan bahwa pembelajaran kooperatif tipe TGT berbantuan alat peraga dapat meningkatkan motivasi belajar siswa dan kemampuan pemahaman matematis siswa dalam kegiatan pembelajaran khususnya pada materi luas bangun datar.

Peningkatan aktiviatas siswa dalam kegiatan pembelajaran kooperatif tipe TGT berbantuan alat peraga sejalan dengan teori belajar konstruktivisme. Dalam pelaksanaannya dilakukan tindakan pada siswa berupa belajar kelompok secara berpasangan. Dengan bekerja secara berpasangan setiap siswa dapat aktifnberperan dalam mengajukan pendapat dalam menyelesaikan masalah dan lebih terbuka dalam berpendapat maupun bertanya. Hal ini lebih efektif sebagaimana dikemukakan oleh Sarbini (2009:6) bahwa keterlibatan siswa bekerja secara berpasangan memberikan dampak yang lebih karena masalah yang diajukan dapat lebih berbobot. Pada kegiatan pembelajaran yang dilakukan siswa bekerja dengan bantuan LAS dan alat peraga. LAS yang diberikan berisi soal-soal yang berkaitan dengan masalah sehari-hari. 
Aktivitas siswa selama pembelajaran pada siklus I belum menunjukkan kategori efektif. Hal ini karena siswa belum terbiasa mengikuti proses pembelajaran kooperatif tipe TGT berbantuan alat peraga. Sebelum siswa terlibat aktif dalam diskusi kelompok untuk melakukan pemecahan masalah berupa LAS yang dihadapinya, siswa yang mampu atau yang pandai lebih senang mengerjakan sendiri lembaran aktivitas siswa (LAS). Siswa yang lambat atau belum mengerti, enggan bertanya kepada teman dan guru tentang masalah yang tidak diketahuinya. Jumlah anggota setiap kelompok juga menjadi penyebab diskusi kurang efektif. Aktivitas siwa untuk bertanya dan menjawab pertanyaan masih rendah.Masih rendahnya aktivitas siswa selama pembelajaran disebabkan siswa belum memiliki kemampuan pemahaman matematis yang baik tentang pembelajaran kooperatif tipe TGT berbantuan alat peraga. Kondisi ini sesuai dengan yang dinyatakan Arends (2008:56) bahwa siswa perlu memahami maksud pembelajaran untuk belajar tentang cara menyelidiki masalah-masalah dan menjadi pelajaran mandiri.

Aktivitas siswa selama pembelajaran kooperatif tipe TGT berbantuan alat peraga pada siklus II menunjukkan kategori efektif denga rata-rata persentase keaktifan sebesar 76.04\%.Siswa terlihat sudah terbiasa dengan situasi pembelajaran kooperatif tipe TGT berbantuan alat peraga.Diskusi dalam kelompok kecil sudah berjalan lancar, siswa yang pintar tidak lagi menyelesaikan sendiri masalah yang diberikan guru.Namun, siswa masih sungkan dalam mengajukan pertanyaan dan menjawab pertanyaan serta memberikan tanggapan kepada teman atau guru pada saat orientasi dan presntasi hasil diskusi.Hal ini disebabkan oleh rendahnya keberanian dan partisipasi siswa dalam menyampaikan dan menjawab pertanyaan atau pendapat dari teman atau guru.Siswa juga masih malu tampil untuk memberikan pendapat dan menjawab pertanyaan dari teman dan guru.Siswa sudah lebih aktif dalam mengajukan pertanyaan dan memberikan jawaban baik dalam diskusi kelompok maupun pada saat presentasi hasil diskusi dan pada saat Time Game Tournamnet.Pada siklus III, aktivitas belajar siswa lebih baik dari dua siklus sebelumnya.Secara umum, menunjukkan kategori sangat efektif dengan rata-rata persentase klasikal aktivitas siswa mencapai $88.29 \%$. 


\section{b. Kemampuan Guru Mengelola Pembelajaran}

Temuan yang diperoleh yaitu pembelajaran melalui pembelajaran kooperatif tipe TGT berbantuan alat peraga pada pembelajaran dapat meningkatkan aktivitas guru. Temuan ini memberikan jawaban terhadap tindakan yang dikemukakan sebelumnya. Dengan demikian dapat disimpulkan bahwa pembelajaran kooperatif tipe TGT berbantuan alat peraga dapat meningkatkan aktivitas guru dalam proses pembelajaran khususnya materi luas bangun datar.

Keberhasilan pembelajaran kooperatif tipe TGT berbantuan alat peraga yang dilakukan dapat dilihat dari aktivitas guru sejalan dengan teori-teori yang mendukung dan hasil beberapa penelitian. Aktivitas yang dilakukan guru berupa beberapa penyampaian keterkaitan pembelajaran dengan kehidupan sehari-hari, memberi stimulus pada siswa, membimbing siswa dalam kegiatan kooperatif tipe TGT berbantuan alat peraga, dan menyediakan alat peraga pembelajaran yang menarik merupakan tindakan guru yang efektif. Menurut Fauzi (2007:10) pengembangan kemampuan mengajukan soal sangat sesuai dengan tujuan pembelaajran di sekoleh dan diperlukan dalam kegiatan pembelajaran. Peranan guru pada pembelajaran kooperatif tipe TGT berbantuan alat peraga sebagai fasilitator dan memberikan bimbingan dalam memecahkan masalah dapat membuat pembelajaran lebih baik dan efektif, sebagaimana dikemukakan oleh Abbas dkk (2007:22). Apa yang dilakukan guru agar proses pembelajaran berjalan lancar, bermoral dan membuat siswa merasa nyaman, serta usaha untuk mengimplementasikan kurikulum dalam kelas merupakan aktivitas yang harus dilakukan (Duffy dan Roehler dalam Whandi, 2009:2).

Hasil pengamatan yang dilakukan terhadap kemampuan guru mengelola pembelajaran pada siklus I belum menunjukkan kategori efektif.Rat-rata persentase kelas adalah $70.40 \%$ dengan kategori cukup.Belum efektifnya pengelolaan pembelajaran yang dilakukan guru karena guru terlihat tidak disiplin dengan waktu yang tertera pada RPP.Guru juga lebih banyak menyampaikan penjelasan kepada siswa, sehingga penggunaan waktu tidak efektif.

Hasil pengmaatan yang dilakukan terhadap kemampuan guru mengelola pembelajaran kooperatif tipe TGT berbantuan alat peraga pada siklus II 
menunjukkan kategori efektif dengan rata-rata persentase kemampuan pengelolaan sebesar $85.11 \%$.Setiap tahapan pembelajaran telah dikelolah dengan baik.Kemampuan guru yang sangat baik terlihat pada aspek membimbing penyelidikan individu dan kelompok.Dimana, semua tahapan atau aspek kegiatan pengelolaan pembelajaran yang perlu ditingkatkan supaya lebih efektif dalam pembelajaran.Skor terendah untuk tahapan orientasi siswa terhadap masalah adalah pada aspek menjelaskan tujuan pembelajaran.Selanjutnya, kemampuan guru mengelola pembelajaran pada siklus III menunjukkan kategori efektif.Ratarata persentase pengelolaan mencapai $92.00 \%$.Keberhasilan ini diperoleh karena pengelolaan pembelajaran yang dilakukan guru selama tindakan berlangsung mencapai kategori sangat efektif. Guru terlihat lebih baik dalam mengelola setiap langkah-langkah pembelajaran mulai dari pembagian kelompok kecil yang heterogen dengan memperhatikan kecocokan dan kenyamanan siswa, tahap orientasi sisswa terhadap masalah sampai kepada evaluasi dan analisis proses penyelesaian masalah. Guru terlihat lebih efektif dalam membimbing diskusi kelompok dan presentasi kerja siswa. Masalah-masalah yang disajikan baik pada LAS dan tes kemampuan pemahaman matematis lebih menarik dan mudah dipahami siswa. Hasil penelitian ini sejalan dengan pendapat Amir (2010:26) yang mengatakan jika pembelajaran diterapkan dengan memenuhi berbagai persyaratan, aturan main, dan keterampilan guru dan siswa maka berbagai manfaat akan diperoleh diantaranya meningkatkan kemampuan pemahaman matematis siswa akan materi ajar. Menurut Kieren dalam Tim MKPBM (2001:71) bahwa rancangan pembelajaran matematika oleh guru berupa tantangan masalah, kerja dalam kelompok kecil, dan diskusi kelas akan membantu siswa belajar secara bermakna.

\section{PENUTUP}

\section{Simpulan}

Berdasarkan hasil analisis data penelitan, dikemukakan beberapa kesimpulan berikut. 
Efektivitas pembelajaran dengan rata-rata kelas untuk efektivitas pembelajaran siswa mengalami peningkatan dari $62.48 \%$ pada siklus I menjadi $76.04 \%$ pada siklus II dan $88.29 \%$ pada siklus III. Dengan demikian, efektivitas siswa kelas VI SD Methodist-12 Medan terhadap pembelajaran kooperatif tipe TGT berbantuan alat peraga pada kompetensi dasar bangun datar adalah sangat efektif.

\section{Saran}

Berdasarkan kesimpulan di atas, disarankan sebagai berikut;

1. Bagi guru yang akan menerapkan pembelajaran kooperatif tipe TGT berbantuan alat peraga harus melakukan persiapan yang matang agar pembelajaran dapat berlangsung dengan baik diantaranya merancang rencana pembelajaran dengan pengelolaan waktu yang efektif pada setiap pertemuan pembelajaran, mempersiapkan segala kebutuhan untuk mendukung suksesnya pembelajaran dan harus mampu merancang masalah-masalah yang kontekstual dan menantang bagi siswa.

2. Bagi siswa agar menunjukkan partisipasi aktif dan respon yang positif pada setiap pembelajaran termasuk pembelajaran kooperatif tipe TGT berbantuan alat peraga, karena melalui pembelajaran kooperatif tipe TGT berbantuan alat peraga akan membentuk individu yang mandiri, terbuka, bertanggungjawab, berpikir kritis, dan mampu menyelesaikan segala masalah yang akan dihadapi dalam kehidupannya.

3. Bagi kepala sekolah atau lembaga agar memfasilitasi dan mendorong para guru dalam melaksanakan pembelajaran kooperatif tipe TGT berbatnuan alat peraga sebagai suatu pembelajaran yang aktif, inovatif, kreatif, efektif, dan menyenangkan bagi siswa untuk meningkatkan prestasi sekolah secara keseluruhan dan dapat menghasilkan generasi bangsa dan negara yang tangguh dalam menghadapi segala permasalahan dalam kehidupannya yang baik.

\section{DAFTAR PUSTAKA}

Anderson, L.W \& Khatwrohl (2001) A. Taxonomy for Learning, Teaching and Assessing: A revision of Bloom's Taxonomy of Educational Objectives: Complete Edition, New York: Longman

Anitah. 2008.Alat Peraga. Surakarta: Sebelas Maret university Press 
Arisandi, Deni .2008. Model-Pembelajaran-Kooperatif-Learning-Tipe-TeamsGames- Tournament- Tgt/, dalam ((http://pkab.wordpress.com, diakses tanggal 03 Februari 2014).

Arnita. 2013.Pengantar Statistik.Medan: Cita Pustaka.

Aqib, Zainal.2008. Penelitian Tindakan Kelas. Bandung: Yrama Widya

Djamarah, Syaiful Bahri.2006. Strategi Belajar Mengajar. Jakarta:Rineka cipta

Hiebert \& Wearne.1993.Long term effect of conceptually-based instruction in mathematics. National Science Foundation Grant (No.8855627), September 1

Iskandar, Agung. 2010.Meningkatkan Kreativitas Pembelajaran Bagi Guru. Jakarta: Bestari Buana Murni

Karim, dkk. 1997. Pendidikan Matematika. Jakarta: DEPDIKNAS

Restika.2009. Aplikasi Model Pembelajaran Kooperatif Tipe TGT Dapat Meningkatkan Motivasi dan Hasil Belajar Biologi Siswa Kelas XI IPA SMA Muhammadiyah 2 Surakarta. Tesis.Jakarta: UPI

Russeffendy. 1992. Pendidikan Matematika 3. Jakarta: DEPDIKNAS

Sanjaya, Wina. 2009. Strategi Pembelajaran. Jakarta: Kencana.

Sardiman, Arif S. 2008. Media Pendidikan.Jakarta : Grapindo Persada

Slameto. 2004. Belajar dan Faktor-Faktor Yang Mepengaruhinya. Jakarta :Rineka Cipta

Slavin.1995.Cooperative Learning: Theory, Research and Practise, Boston Ally and Bacon

Sudjana. 1991. Alat-Peraga dalam pembelajaran (http:/ love inmaret.blogspot.co m,diakses 6 maret 2014.

Suriyanti.2011. Perbedaan Model pembelajaran Kooperatif Tipe TGT dan Model Pembelajaran Konvensional Pada Hasil Belajar Ekonomi Siswa Kelas X5.Tesis. Medan: Pascasarjana Unimed.

Susanto, Ahmad. 2013. Teori Belajar Pembelajaran. Jakarta: Kencana

Wiharto. 2009. Upaya peningkatan Pemahaman Konsep Matematika Dalam Bahasa Inggris Siswa Kelas VII RSBI di SMP Negeri 1 Bantul. (On line) 